\title{
Learning Small Business Management in an Interactive Environment with Blogs and Simulations
}

\author{
Lisa Kahle-Piasecki \\ Associate Professor of Management \& Information Systems, Tiffin University, 155 Miami Street, Tiffin, Ohio, USA \\ 44883, Office: 419.448.5129 EST USA \\ Email: lisapiasecki@gmail.com; piaseckil@tiffin.edu
}

\begin{abstract}
The acceptance of digital games in the classroom continues to increase each year. Efforts to assess the effectiveness on learning show advantages and limitations. The purpose of this study is to examine how the use of digital games or simulations, combined with the use of a blog for reflection on course material, supports learning in the classroom. Students in a Spring 2014, Spring 2015 and Spring 2017 Small Business Management class were required to complete blog posts and play a small business simulation throughout the semester. At the end of the course, a survey was conducted and students were asked to assess items in learning categories on a five-point Likert-type scale, which indicated the amount of agreement between the items and the students. Descriptive analyses were conducted to determine the frequency and percentage of respondents in agreement or disagreement for each question. This research will discuss the results of the study.
\end{abstract}

Keywords: Blogs; simulations; small business management

\section{Introduction}

Today's college students are part of the generation, defined as millennials, born approximately between 1979 and 1995. They are the first generation to have unlimited technological platforms to express themselves (Hyder, 2014) and they are frequently called, "digital natives." This generation uses technology and is deeply ingrained in its use (Accenture, 2010). They have generational characteristics that are unique; one of those characteristics is that they expect to be engaged in their learning and not just lectured to. Additionally, today's college students want connections between new material and real world applications (North Illinois University, n.d.). Educational games and simulations can be useful, because they represent some type of situation that players use a computer system to interact with. Using games or simulations for learning, resembles this generation's approach to solving problems. Games and simulations help students visualize complex systems (North Illinois University, n.d.), such as operating a small business, so that students better understand a specific environment.

As college students from the millennial generation bring technology experience with them in the classroom, integrating technology within the higher education curriculum can be valuable to support students in their learning, especially when technology usage is aligned with course learning objectives and faculty are trained in using the technology. However, some higher education faculty are reluctant to introduce technology into their classroom for reasons which could include, lack of training, lack of awareness of useful technologies, and lack of knowledge on research to support technology use. Millennials are technologically-oriented, and many professors do not share their skills and attitudes concerning technology (Papp \& Matulich, n.d.).

In a review of the literature by McCorkle, McCorkle and Payan (2014), 1,127 articles on blogs revealed only 24 articles concerning using blogs in higher education and only $8 \%$ of those were in business. Despite research that supports the use of blogs for business operations and that shows blogs are frequently used in business (Mohr, n.d.), little research exists on using blogs combined with a simulation in the higher education business classroom.

The purpose of this study is to examine how the use of a simulation combined with the use of blogs for reflection on course material, supports student learning in the university business classroom.

\subsection{Games and Simulations}


Business games have been used in university classrooms for over 50 years (Faria, \& Wellington, 2005). Games and simulations have come a long ways since the 1980s when arcades and video game consoles became popular. Even though some of today's faculty are from Generation X, which grew up with Atari consoles, they are much different from the millennial generation, which "grew-up with video-game controllers in their hands" (Holley, 2014, para. 3). Using games and simulations in learning, is much more acceptable and widespread today because of the millennial generation. For example, the U.S. military uses virtual training so that young trainees have to learn to perform complex tasks in an environment they are familiar with (Holley, 2014). Defense contractor Raytheon, has been training U.S. service members on video games, using the same sort of consoles and software as videogame makers (Holley, 2014) and games for learning are expected to be one of the top design trends in 2015 for corporate learning specialists and instructional designers (LeBlanc Vaughan, 2015).

It is important to distinguish the difference between a game and simulation. The goal of a game is to determine who wins or loses with competitors; the game has constraints and a linear objective. A simulation however, tries to find the relationship between cause and consequence (Tao, Yeh \& Hung, 2012).

Using a simulation for operating a small business, for example, lets students explore different functions of business processes and learn by doing (Papp \& Matulich, n.d.). If the simulation also has a competitive component where students can compete against each other, this can lead to even more engagement in the learning process. It is important to create a meaningful connection with a simulation and the rest of the course to create a more powerful overall experience for the students (Lang, 2014). Students can run an actual business in a game or simulation, but they should also support their learning on running a business, with additional course material, such as a textbook.

Using simulations and games in learning is not without its critics. Some believe, using games for learning makes players lazy or socially awkward but some experts consider that "serious games and virtual environments are the future of education" (Steinberg, 2011, para. 10). Business game users have been concerned with the meaningfulness of business games as teaching tools. Most of the business game simulations give users the opportunity to formulate and test business strategies - one of the major objectives of business management courses (Faria \& Wellington, 2005). In a research study by Faria and Wellington (2005), business gaming was found to be a relevant and meaningful teaching tool and a discipline specific based simulation, can be helpful in supporting the overall learning assurance process (Hall \& Ko, 2006).

Tao, et al (2012) found that students using a simulation in a business class continually improved their performance in the game when they had greater dynamics in group discussion. In another study, perceived ease of use in playing the game and attractiveness of the game played a critical role in determining the student satisfaction (Tao, Cheng, \& Sun, 2009). In a research study (Moore, Herzog \& Perkins, 2013) that used a simulation for chemistry, 92\% responded that they thought the simulation would be somewhat to very useful to their learning.

In this study, the simulation used did not provide an opportunity for team play. Each student interacted with the simulation as an individual user. The set-up of a business was determined individually, and students were allowed to pick their choice of type of business among four choices, (1) ice cream store, (2) sandwich shop, (3) music store, and (4) coffee shop. The simulation used in this study is a GoVenture product.

\subsection{Blogs}

A blog is a place on the web that is a page or site for posting and publishing information. The word 'blog' is shortened from the word "Weblog" which in its earliest form, was a type of web page that required a knowledge of code and required updating files stored on a server anytime a change was made (Richardson, 2010). Initial uses of blogs were for political commentary and pages of opinion. Blogs have since evolved into places of conversation and engaged interaction through the posting and sharing of daily ideas, questions, and links to other sites.

\subsection{Classroom Uses}


Using blogs for reflection on course content is a helpful digital tool that can support and enhance student learning (McCorkle, McCorkle \& Payan, 2014), by providing a deeper classroom communication connection (Alexandar \& Bach, 2013; Miller \& Williams, 2013), providing a place for a reflection on course material both by posting original thoughts and reading others posts, and providing a digital archive of learning experiences. By interacting with their peers, students are more engaged in the course content and the learning community (Alexander \& Bach, 2013) and can learn from each other using technology in a meaningful way (Lacina \& Griffith, 2013). Blogging can be an effective tool to increase participation by students because a blog gives each student in the class an opportunity to share their opinions at their own pace. Whereas, in a traditional classroom, often the most outspoken and extroverted students share their opinions naturally, while quiet or introverted students are more reluctant to participate in classroom discussions.

Blogs can be used individually, like a personal journal, or as a classroom-wide spot where students read and post to each other's writings.

Machado (2011) for example, used both private individual blogs and a classroom discussion board to examine a preference based on gender, for student discourse. Students in the study preferred the discussion board to personal blogs and there was no significant difference in the number of times females and males posted on their personal blogs or the discussion board. The discussion board allowed for social interaction whereas, the blogs were private and only read by the instructor.

While research supports the use of a blog to facilitate teaching and learning, using a blog in the classroom has its critics. Levy (2009) observed that the use of a blog is very labor-intensive for the instructor and blogging lacks experimental studies using comparative control groups. It is difficult therefore, to assess whether the amount of time spent maintaining the blog, benefits students' learning performance. However, in a later study by Lin, Lin and Hsu (2011), two classrooms of English as a second language were studied. One classroom used a blog, the other was taught in a traditional way, using paper-based assignments. The researchers found both approaches improved student writers' performance and that students taught in a traditional format had a similar performance increase in their writing ability. The researchers argue that the use of blogs to improve students writing abilities is not worth pursuing, given the significant effort and amount of time spent on the design and maintenance of the blogs.

In a study by McCorkle, McCorkle and Payan, 2014, students in an e-marketing course and in a study abroad program were required to use a blog. Some negative attitudes using blogs were reported from students because of the concern on the time spent blogging, privacy issues, and discomfort giving feedback to other students and technology-related issues. Overall, however, students enjoyed the blogging experience and recommended that the blog continue as a useful tool in the course.

A trait of millennial's is their preference for reflecting on their learning. Reflective learning can be defined as, standing back, making decisions, and evaluating learning (Taylor, Marienau \& Fiddler, 2000). Using this practice in the classroom, enhanced by technology is important. Reflective blogging emerged as an effective digital tool to create a classroom community in a young adult fiction course by supporting personal exploration of the course material, inviting peer feedback and comments and promoting a broad and deep class communication (Alexander \& Bach, 2013). The use of blogs in this study reinforced some of the goals of the course, which had technology playing a significant role.

\subsection{Establishing a Blog}

The purpose of using a blog in the classroom should be clearly defined and linked to the course learning objectives. In this study, the use of the blog and small business simulation, supported three of the small business management course learning objectives; (1) to understand and demonstrate the use of technology and e-business, (2) acknowledge the constant need to examine how decisions affect cash flow, and (3) identify some of the major hazards that small business managers face. Blogs are also important for small businesses because they can help draw online traffic, nurture and convert customers, grow demand and interest in products or services and keep current customers engaged (Content Marketing, 2017). Additionally, using blogs in a business class teaches students about interactive media as a marketing, advertising or business tool (McCorkle, McCorkle \& Payan, 2014).

It is important before beginning a blog, for the instructor to decide on the frequency of the posts and types of posts required for an effective classroom blog. Blogging is an informal medium compared to 
other written assignments and considered a "genre of writing with its own demands" (Kirkup, 2010, p. 77).

Blogs can be useful for reinforcing the responsibility of ideas because the classroom community can read and comment on posts (Buechler, 2010). Although it is informal writing, guidelines should be established for bloggings' use as a digital learning tool. The ease of information access and ease of posting comments can be of concern and a risk in using a blog in the classroom or in a work environment (Dubose, 2011). Miller and Williams (2013) found that a challenge in using a blog was the sometimes casual and extremely informal language students sometimes reverted to in their blog posts. Instructors should establish protocols and a clear rubric with grading expectations to address this. Students need to be aware of the instructor guidelines and trained in appropriate techniques for writing posts and commenting to others posts. For example, students should be respectful of different opinions and avoid any comments that could be considered offensive or that are defamatory to classmates. Instructors have an obligation to protect students from unintended harm and must be clear in their policies when using a technology such as a blog or other type of social media.

\subsection{Purpose and Research Questions}

The purpose of this study is to examine how the use of a simulation combined with the use of a blog for reflection on course material, supports student learning in the university business classroom.

Small business management faculty need to prepare future small business owners by teaching effective uses of technology to support business operations. Small business management faculty should also try to give their students as much exposure to small business operations as possible, preparing their students to own and operate a small business and avoid financial failure and limited profitability. By examining the use of two technologies in the business classroom, blogs and simulations, faculty can better understand student perceptions of their learning with technology and better prepare future small business owners with technology tools to succeed in business.

The research questions that were addressed in this study are as follows:

R1: How does the use of a blog for reflection, support learning in the small business management classroom?

R2: How does the use of a simulation, support learning in the small business management classroom?

R3: How does using a blog to reflect on a simulation, support learning in the small business management classroom?

\section{Methodology}

This study used a survey to examine how the use of a blog for reflection on course material combined with the use of a small business simulation supported learning in the business classroom. The survey was conducted with undergraduate business students enrolled in one section of a small business management course, during the spring 2014 semester $(n=15)$, during the spring 2015 semester $(n=18)$ and during the spring 2017 semester $(\mathrm{n}=10)$.

The research questions that were addressed in this study are as follows:

R1: How does the use of a blog for reflection, support learning in the small business management classroom?

R2: How does the use of a simulation, support learning in the small business management classroom?

R3: How does using a blog to reflect on a simulation, support learning in the small business management classroom?

In this study, the instructor created a private classroom blog using Google Blogger. Students were given five prompts throughout the semester to reflect on and post to. Students were able to see and read through their classmates' posts, and required to post responses to each other. The blog was not viewable by the public and the instructor controlled the access and settings.

The main purpose of the blog was to provide support for the small business simulation. The small business simulation was an individual assignment but students could benefit from the collaborative aspect of using a blog.

The simulation allowed students to create their business from a selection of four possible choices; (1) 
ice cream store, (2) sandwich shop, (3) coffee shop, and (4) music store. Students were able to select the name for the business and were required to submit weekly performance reports on the profitability, employee and customer satisfaction, and overall stress level of the business owner. Students played the game for the entire semester.

Students were asked to discuss positive and negative issues that arose when running their own business in the simulation (see Table 1). In other prompts, students were asked to further explore owning and operating a small business. Students described their experiences using the software and running their own business and expressed their opinions. This personal experience is considered highly important in blogging and is different from other forms of traditional academic writing where students are required to follow traditional, long, and analytical texts (Boyd, 2013; Kirkup, 2010).

Table 1. Listing of the topics for blog reflections

\begin{tabular}{ll}
\hline 1 & $\begin{array}{l}\text { For the first blog, discuss anything related to setting-up your business in GoVenture. Any questions? } \\
\text { Comments? Frustrations? }\end{array}$ \\
\hline 2 & Discuss the type of business you selected for the GoVenture simulation and why you selected it? \\
\hline 3 & $\begin{array}{l}\text { Describe how you are doing in your business. Are you halfway through the first year? How is your customer } \\
\text { satisfaction? }\end{array}$ \\
\hline 4 & $\begin{array}{l}\text { We are almost finished playing the simulation. Describe how you feel about your profits? How is your level of } \\
\text { employee satisfaction? }\end{array}$ \\
\hline 5 & $\begin{array}{l}\text { Post a few sentences regarding using GoVenture for Small Business. How did you end your simulation? Was } \\
\text { your business as profitable as you expected? Better? }\end{array}$ \\
\hline
\end{tabular}

\section{Instrumentation and Data Collection}

Data were collected using a survey instrument adapted from a research study on the use of blogs to support teaching and learning (Churchill, 2009; Teclehaimanot \& Kahle-Piasecki, 2011). Changes were made in the instrument for application to a business class and to include the small business simulation. All items were answered on a five-point Likert-type scale, which indicates the amount of agreement between the items and the students: strongly disagree, disagree, no opinion, agree, and strongly agree. The survey included demographic items such as, gender and class rank and also asked students about their prior experience reading blogs or using simulations.

Questionnaires were given to all students enrolled in the course at the end of the semester during the last class meeting $(\mathrm{n}=43)$.

\subsection{Sample}

The participants in this study were undergraduate students enrolled in three sections of a small business management class in the School of Business in a small, Midwestern university $(\mathrm{n}=43)$.

\subsection{Procedure}

The researcher introduced the study and explained the instrument during the last class meeting of the semester. The instrument was distributed, completed and collected with the researcher present to answer any questions.

\subsection{Data Analysis}

The statistical software, SPSS (Version 17.0) was used for all quantitative analyses. Descriptive analysis was conducted to determine the frequency and percentage of respondents in agreement or disagreement for each question.

\subsection{Limitations}


In any research study, the validity of the research project and the ability of the researcher to draw meaningful and defensible conclusions from the data is subject to limitations (Leedy \& Ormrod, 2005). One limitation from the study is that the results may not be generalizable to college students in universities outside of the sample. Additionally, the sample is small.

Another limitation of the study is the use of self-report data, which can have perception differences by the respondent and be intentionally misrepresented to have socially acceptable responses.

\section{Results}

At the end of the semester, questionnaires as shown in Table 2, were administered to the students. Students were asked to assess items on a five point scale; (1) strongly disagree, (2) disagree, (3) no opinion, (4) agree, and (5) strongly agree. The results were tabulated to determine responses under three categories; (1) which aspects contributed most to the students' learning, (2) which aspects on blogging they liked, and (3) which aspects on using the small business simulation they liked.

Of the 17 students enrolled in the course during Spring 2014, 15 were in class and completed the paper survey. Of those 15 students, six were female and nine were male. One student circled the class rank as sophomore, four circled junior, and 10 circled senior.

Of the 22 students enrolled in the course during Spring 2015, 18 were in class and completed the paper survey. Of those 18 students, 11 were male, five were female, two did not respond. Eleven students circled junior, five circled senior, and two did not respond.

Of the 12 students enrolled in the course during Spring 2017, 10 were in class and completed the paper survey. Of those 10 students, six were male and four were female. Eight students circled the class rank as senior, two circled junior.

Table 2. Questionnaire

\begin{tabular}{|c|c|c|c|}
\hline Learning in this course & $\bar{n}=$ & $\begin{array}{l}\text { \% Agree } \\
(\mathrm{n})\end{array}$ & $\begin{array}{l}\text { \% Disagree } \\
(\mathbf{n})\end{array}$ \\
\hline 1.1. Compared to other courses, in this course I am learning much more. & 43 & $83.7(36)$ & $9.3(4)$ \\
\hline $\begin{array}{l}\text { 1.2. In this course, I believe I will get a higher final grade than in other } \\
\text { courses. }\end{array}$ & 43 & $41.8(18)$ & $30.2(13)$ \\
\hline 1.3. Overall in this course, blogging facilitated and contributed to my learning. & 43 & $60.5(26)$ & $16.3(7)$ \\
\hline 1.4. Due to class blogs, I felt an important part of our classroom community. & 43 & $62.8(27)$ & $14.0(6)$ \\
\hline 1.5. With blogs, it appears that other students were supportive of my learning. & 43 & $69.8(30)$ & $2.3(1)$ \\
\hline $\begin{array}{l}\text { 1.6. Overall in this course, using the simulation facilitated and contributed to } \\
\text { my learning. }\end{array}$ & 43 & $79.1(34)$ & $11.6(5)$ \\
\hline \multicolumn{4}{|l|}{ Aspects of blogging I liked } \\
\hline 2.1. Reflecting on the blog topic and writing about it. & 43 & $67.4(29)$ & $9.3(4)$ \\
\hline $\begin{array}{l}\text { 2.2. Receiving comments from other class members about my postings and } \\
\text { work. }\end{array}$ & 43 & $60.5(26)$ & $4.7(2)$ \\
\hline $\begin{array}{l}\text { 2.3. Receiving comments from the instructor in relation to my postings and } \\
\text { work. }\end{array}$ & 43 & $81.4(35)$ & $2.3(1)$ \\
\hline 2.4 Learning how to use the blog technology. & 43 & $72.1(31)$ & $9.3(4)$ \\
\hline \multicolumn{4}{|l|}{ Aspects on using the simulation I liked } \\
\hline 3.1. Playing the game simulation. & 43 & $53.5(23)$ & $25.6(11)$ \\
\hline $\begin{array}{l}\text { 3.2. Learning the day-to-day experiences involved in starting and running a } \\
\text { small business. }\end{array}$ & 43 & $74.4(32)$ & $11.6(5)$ \\
\hline 3.3. Learning in an interactive environment. & 43 & $86.0(37)$ & $2.3(1)$ \\
\hline 3.4. Discussing the simulation with other students using a blog. & 43 & $69.8(30)$ & $11.6(5)$ \\
\hline
\end{tabular}

During the second semester, a significant upgrade in the simulation software several weeks into the beginning of the semester occurred. Students needed to download updates and various patches to get the simulation to work correctly and students expressed frustration with using the software.

The category Agree includes the choices of Strongly Agree and Agree. Strongly Disagree and Disagree 
choices were collapsed into Disagree. The No Opinion responses were not included in the table.

\subsection{Learning in This Course}

Data from the survey show that the majority of students felt blogging facilitated and contributed to their learning (item 1.3) and using the simulation facilitated and contributed to their learning (item 1.6).

\subsection{Aspects on Blogging}

The majority of students in the survey liked reflecting on the blog topic and writing about it (item 2.1) and they also liked receiving comments from the instructor in relation to their posts and work (item 2.3).

\subsection{Aspects on Using the Simulation}

Students liked learning the day-to-day experiences involved with starting and running a business (item 3.2 ) and learning in an interactive environment (item 3.4).

\section{Discussion}

Using technology in the classroom should serve a purpose to enhance learning and contribute to the learning objectives of the course. In this study, more than half of the students $(n=26,61 \%)$ felt that blogging facilitated and contributed to their learning, and $79 \%(n=34)$ of students felt using the simulation facilitated and contributed to their learning. Although, slightly more students felt using the simulation contributed to their learning, the majority of students $(n=30)$ felt discussing the simulation with other students using a blog was an important aspect of using the simulation. The results of the study suggest that combining both a blog and simulation were effective in the learning of the course and that students liked both the blog and simulation and learning in an interactive environment was important to almost all of the students $(\mathrm{n}=37,86 \%)$. This supports earlier studies that show having discussion (Tao et al, 2012) and a perception that a simulation is easy to use (Tao, et al, 2009), can enhance the leaners satisfaction in a course. When combining the use of a blog with a simulation, learning can be positively affected because the blog offers students a place to support their individual simulation learning within a classroom community, and it could lead to a perception that the game is attractive and easy to use by allowing discussion with other classmates on using the simulation.

\section{Implication}

Because the millennial generation continues to make up the student population in higher education, an expectation for integrating technology in the classroom will continue to increase. Technology integration should align with the course learning objectives and support and enhance the overall learning of the course. Future research on using technology in business classes with a larger sample should be conducted, and research should be conducted examining other technology tools in the business class.

\section{References}

1. Accenture. (2010). Jumping the boundaries of corporate IT: Millennial generation is rocking the foundation of IT. Retrieved from http://www.accenture.com/us-en/Pages/insight-millennials-technology-overview.aspx

2. Alexander, J. \& Bach, D. (2013). Creating classroom community with reflective blogs. The International Journal of Technology, Knowledge, and Society, 9, 17-29.

3. Boyd, P. (2013). Blogging in the classroom: Using technologies to promote learner-centered pedagogies. The Researcher: An Interdisciplinary Journal, 26(3), 85-113.

4. Buechler, S. (2010). Using Web 2.0 to collaborate. Business Communication Quarterly, 73(4), 439-443. doi:10.1177/1080569910385381

5. Churchill, D. (2009). Educational applications of web 2.0: Using blogs to support teaching and learning. British 
Journal of Educational Technology, 40(1), 179-183.

6. Content Marketing. (2017, May 13). 5 ways a blog can help your business right now. Retrieved from https://www.searchenginejournal.com/benefits-of-blogging-for-business/195037/

7. Dubose, C. (2011). The social media revolution. Radiologic Technology, 83(2), 112-119.

8. Faria, A.J., \& Wellington, W. (2005). Validating business gaming: Business game conformity with PIMS findings. Simulation \& Gaming, 36(2). Doi: 10.1177/1046878105275454

9. Hall, O., \& Ko, K. (2006). Learning assurance using business simulations: Applications to executive management education. Developments in Business Simulation and Experiential Learning, 33, 1-6.

10. Holley, P. (2014, December 2). The military is now using video games to train millennials in Cold War technology. The Washington Post. Retrieved from http://www.washingtonpost.com/news/postnation/wp/2014/12/02/the-military-is-now-using-video-games-to-train-millennials-in-cold-war-technology/

11. Hyder, S. (March 4, 2014). Here's what you need to know about millennials. Forbes. Retrieved from http://www.forbes.com/sites/shamakabani/2014/03/04/here-is-what-you-need-to-know-about-millennials/

12. Kirkup, G. (2010). Academic blogging, academic practice and academic identity. London Review of Education, 8(1), 75-84. doi: 10.1080/14748460903557803

13. Lacina, J., \& Griffith, R. (2013). Blogging as a means of crafting writing. The Reading Teacher, 66(4), 316.

14. Lang, J. (2014, September 19). How students learn from games. The Chronicle of Higher Education, B34-B35.

15. LeBlanc Vaughan, S. (2015, February 2). 2015 Instructional design trends compass: Calling IDs to action. elearning Industry. Retrieved from http://elearningindustry.com/2015-instructional-design-trends-compasscalling-ids-action

16. Leedy, P. \& Ormrod, J. (2005). Practical research: Planning and design( $8^{\text {th }}$ edition). Columbus, Ohio: Pearson Merrill Prentice Hall.

17. Levy, M. (2009). Technologies in use for second language learning. The Modern Language Journal, 93(sI), 769782. doi: $10.1111 / \mathrm{j} .1540-4781.2009 .00972 . \mathrm{x}$

18. Lin, M., Lin, C., \& Hsu, P. (2011). The unrealistic claims for the effects of classroom blogging on English as a second language, students' writing performance. British Journal of Educational Technology, 42(6), 148-151. doi:10.1111/j.1467-8535.2011.01225.x

19. Machado, C. (2011). Gender differences in student discourse on discussion board and blogs: An instructor's quest to create a level playing field in a hybrid classroom. Journal of Interactive Online Learning, 10(1), 36-48.

20. McCorkle, D., McCorkle, Y., \& Payan, J. (2014). Using blogs in the marketing and advertising classroom: Exploratory insights and recommendations for future use. Journal of Advertising Education, Spring, 24-35.

21. Miller, W., \& Williams, R. (2013). Preservice teachers and blogs: An invitation to extended reflection and conversation. Art Education, May, 47-52.

22. Mohr, A. (n.d.). Do businesses use Blogger? Small Business Chronicle. Retrieved from http://smallbusiness. chron.com/businesses-use-blogger-21628.html

23. Moore, E., Herzog, T., \& Perkins, K. (2013). Interactive simulations as implicit support for guided inquiry. Chemistry Education Research and Practice 14, 257-268.

24. Northern Illinois University. (n.d.). Millenials: Our newest generation in higher education. Faculty Development and Instructional Design Center, 1-3.

25. Papp, R., Matulich, E. (n.d.). Negotiation the deal: Using technology to reach the millennials. Journal of Behavioral Studies in Business, 1-12.

26. Richardson, W. (2010). Blogs, Wikis, Podcasts, and other Powerful Web Tools for Classrooms (3 ${ }^{\text {rd }}$ ed.). Corwin Press.

27. Steinberg, S. (2011, January 31). How video games can make you smarter. Special to CNN. Retrieved from http://www.cnn.com/2011/TECH/gaming.gadgets/01/31/video.games.smarter.steinberg/

28. Tao, Y., Yeh, C., Hung, K. (2012). Effects of the heterogeneity of game complexity and user population in learning performance of business simulation games. Computers $\mathcal{E}$ Education, 59, 1350-1360.

29. Taylor, K., Marienau, C., \& Fiddler, M. (2000). Developing Adult Learners. Jossey-Bass: San Franciso.

30. Teclehaimanot, B., \& Kahle-Piasecki, L. (2010). Web 2.0 in the preservice teacher classroom: Using blogs to enhance learning. In C. Crawford et al. (Eds.), Proceedings of Society for Information Technology $\mathcal{E}$ Teacher Education International Conference 2010 (pp. 2402-2406). Chesapeake, VA: AACE. 